\title{
Triterpenoids from Ainsliaea latifolia and Their Cyclooxyenase-2 (COX-2) Inhibitory Activities
}

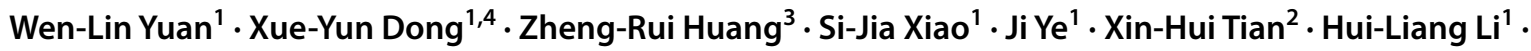 \\ Yun-Heng Shen ${ }^{1}$ (D) . Wei-Dong Zhang ${ }^{1,2}$
}

Received: 27 October 2019 / Accepted: 19 November 2019 / Published online: 30 November 2019

(c) The Author(s) 2019

\begin{abstract}
Eight new triterpenoids were isolated from Ainsliaea latifolia. The structures of these compounds were elucidated by interpretation of spectroscopic data, including HRESIMS and NMR data. Compounds 4-6 are identified as rare trinorcucurbitane or tetranorcucurbitane triterpenoids. The absolute configurations of compounds $\mathbf{1}$ and $\mathbf{2}$ were confirmed by Snatzke's method. All compounds were evaluated for their inhibition against cyclooxyenase-2 (COX-2), in which compound $\mathbf{4}$ showed significant inhibitory effect against COX-2 with $\mathrm{IC}_{50}$ value of $3.98 \pm 0.32 \mu \mathrm{M}$, comparable to that of positive control NS-398 $\left(\mathrm{IC}_{50} 4.14 \pm 0.28 \mu \mathrm{M}\right)$.
\end{abstract}

\section{Graphic Abstract}

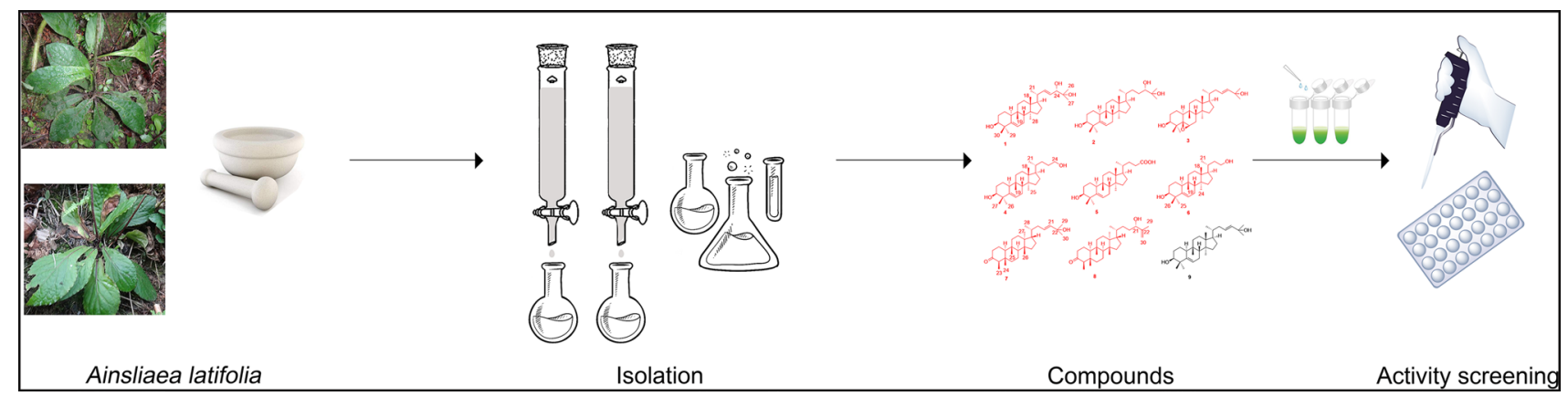

Keywords Ainsliaea latifolia $\cdot$ Triterpenoids $\cdot$ COX-2 $\cdot$ Cucurbitane

Dedicated to Professor Han-Dong Sun on the occasion of his 80th birthday.

Wen-Lin Yuan and Xue-Yun Dong have contributed equally to this work.

Electronic supplementary material The online version of this article (https://doi.org/10.1007/s13659-019-00228-x) contains supplementary material, which is available to authorized users.

Yun-Heng Shen

shenyunheng@hotmail.com

Wei-Dong Zhang

wdzhangy@hotmail.com

Extended author information available on the last page of the article

\section{Introduction}

The genus Ainsliaea (Compositae), a medicinally important genus in traditional Chinese medicine, comprises about 70 species worldwide, in which most Ainsliaea plants are distributed in Southeast Asia. Previous investigations have reported the presence of sesquiterpenoids, sesquiterpene lactone dimers, triterpenoids, steroids and flavonoids in Ainsliaea species [1-3]. Some of them exhibited diverse biological activities, including cytotoxic, antiviral, antibacterial and anti-inflammatory activities [4-6].

Ainsliaea latifolia grows mainly in the southwest of China and has long been used as a folk medicine for the treatment of rhumatism, traumatic injuries, edema, stomachache, and 
anorexia [7]. In Ainsliaea species, sesquiterpenoids are usually considered as characteristic chemical constituents. However, in our study of the chemical constituents from A. latifolia, eight new triterpenoids (1-8) and one known triterpenoid (9) were isolated and identified from the whole plants of A. latifolia. Herein, we described the isolation and structural elucidation of compounds $\mathbf{1 - 8}$, as well as their inhibition against cyclooxyenase-2 (COX-2).

\section{Results and Discussion}

The $\mathrm{CHCl}_{3}$-soluble of the EtOH- $\mathrm{H}_{2} \mathrm{O}(80: 20$, v/v) extract of A. latifolia was purified by repeated column chromatography (CC) over silica gel, Sephadex LH-20, and semi-preparative HPLC to yield eight new and one known compounds. By comparison of their NMR and MS data with the published references, the known compound $\mathbf{9}$ was then identified as one triterpenoid cucurbita-5,23-diene-3 $\beta, 25$-diol (9) [8]. The structures of eight new triterpenoids were determined by analysis of HRESIMS and NMR spectroscopic data (Fig. 1).

Compound 1 was isolated as white solid. Its molecular formula $\left(\mathrm{C}_{30} \mathrm{H}_{50} \mathrm{O}_{3}\right)$, ascertained via high resolution ESI-MS analysis, indicated six degrees of unsaturation. The ${ }^{1} \mathrm{H}$ NMR spectrum of $\mathbf{1}$ (Table 1) exhibited signals for three olefinic protons at $\delta_{\mathrm{H}} 5.59(2 \mathrm{H}), 5.42(1 \mathrm{H}, \mathrm{m})$, two oxygenated methine groups at $\delta_{\mathrm{H}} 3.83(1 \mathrm{H}, \mathrm{d}, J=7.1 \mathrm{~Hz}), 3.47(1 \mathrm{H}$, brt, $J=2.5 \mathrm{~Hz})$, eight methyl groups $\left(\delta_{\mathrm{H}} 1.20,1.14,1.13,1.02\right.$, $1.00,0.92,0.87,0.81)$. The ${ }^{13} \mathrm{C}$ NMR spectrum revealed the presence of thirty carbon signals including four olefinic carbons at $\delta_{\mathrm{C}} 141.2,141.3,125.7$ and 121.4 , three oxygenated carbons at $\delta_{\mathrm{C}} 79.7,76.6$ and 72.9, and eight methyl carbons at $\delta_{\mathrm{C}} 28.0,27.2,26.3,25.4,23.7,20.4,17.8$ and 15.7. The other carbon signals were assigned to seven methylenes, four methines, and four quaternary carbons. A comparison of these carbon resonances with those of the related cucurbitane-type triterpenoids suggested that $\mathbf{1}$ possessed the same cucurbitane skeleton, and the differences between the spectroscopic data of $\mathbf{1}$ and those of known compound $\mathbf{9}$ were

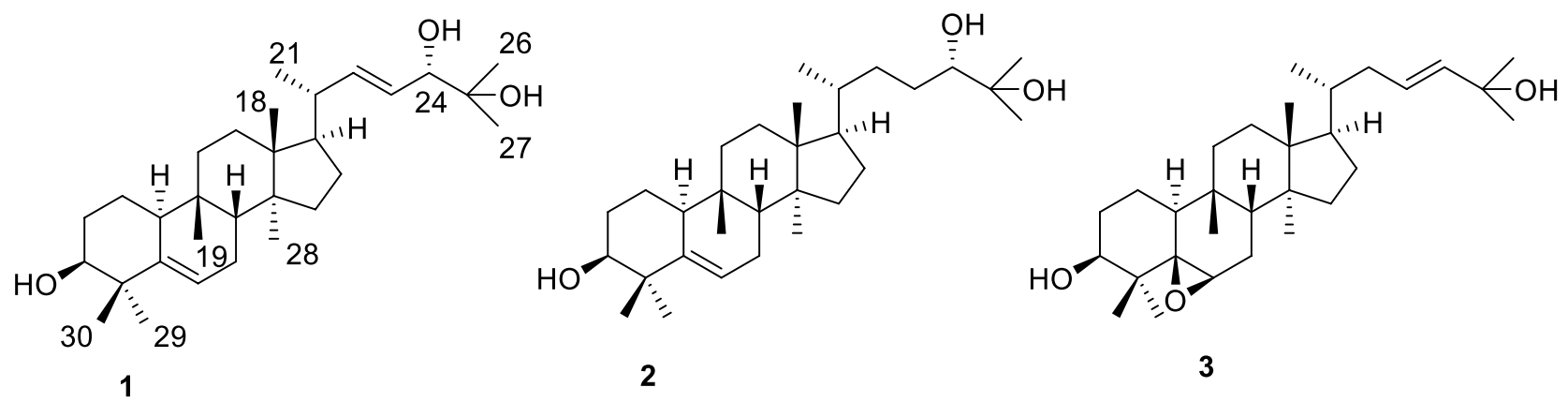

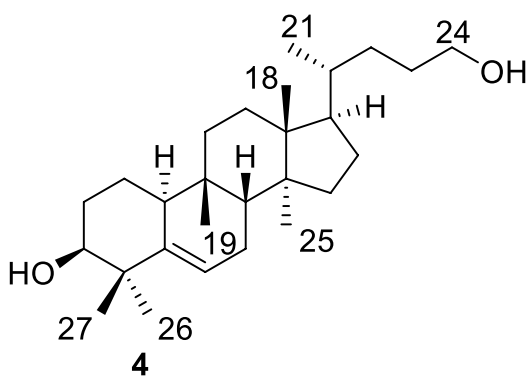

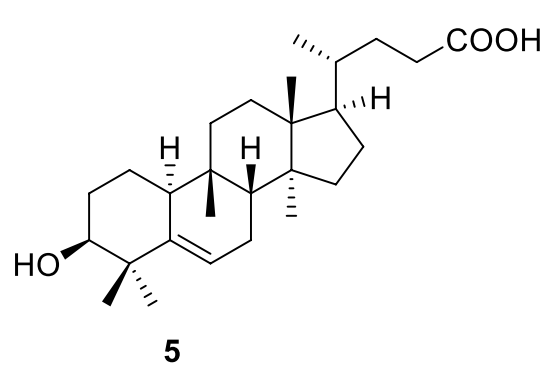

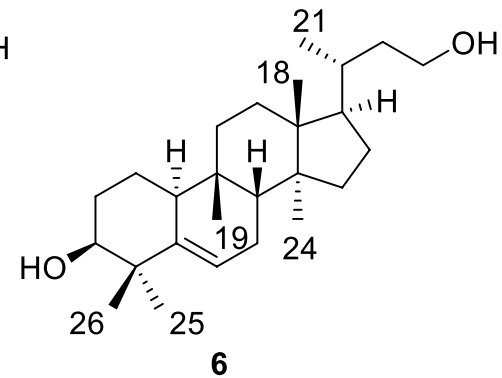

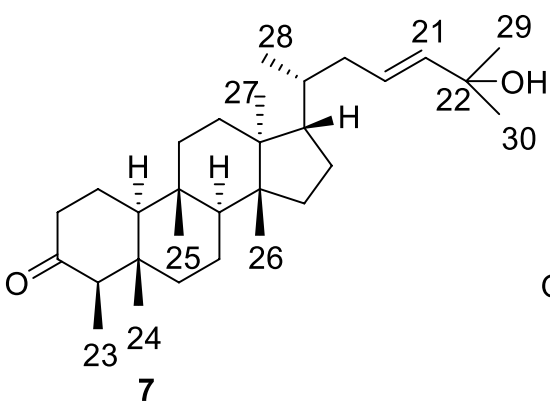

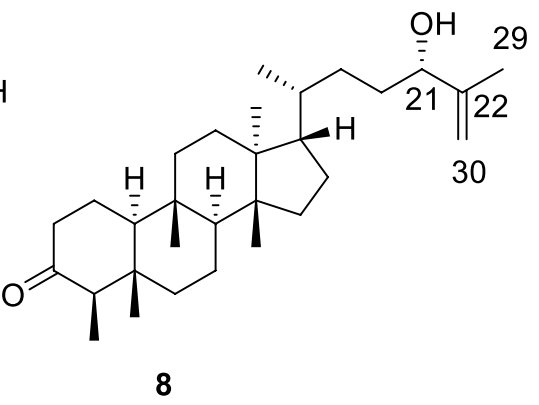

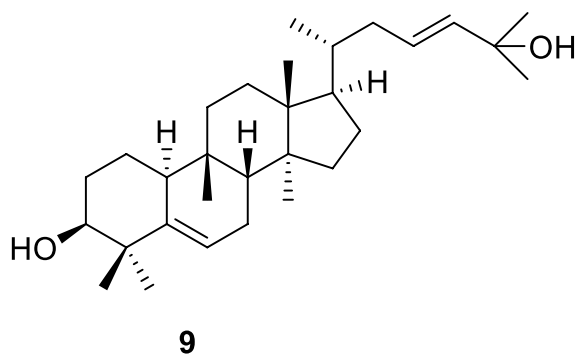

Fig. 1 Chemical structures of 1-9 
Table $1{ }^{1} \mathrm{H}(500 \mathrm{MHz})$ and ${ }^{13} \mathrm{C}$ (125 MHz) NMR spectroscopic data of compounds $\mathbf{1}-\mathbf{4}$ in $\mathrm{CDCl}_{3}$

\begin{tabular}{|c|c|c|c|c|c|c|c|c|}
\hline \multirow[t]{2}{*}{ No. } & \multicolumn{2}{|c|}{ Compound 1} & \multicolumn{2}{|c|}{ Compound 2} & \multicolumn{2}{|c|}{ Compound $\mathbf{3}$} & \multicolumn{2}{|c|}{ Compound 4} \\
\hline & $\delta_{\mathrm{C}}$ & $\delta_{\mathrm{H}}(J$ in $\mathrm{Hz})$ & $\delta_{\mathrm{C}}$ & $\delta_{\mathrm{H}}(J$ in $\mathrm{Hz})$ & $\delta_{\mathrm{C}}$ & $\delta_{\mathrm{H}}(J$ in $\mathrm{Hz})$ & $\delta_{\mathrm{C}}$ & $\delta_{\mathrm{H}}(J$ in $\mathrm{Hz})$ \\
\hline 1 & 21.1 & $\begin{array}{l}1.58, \mathrm{~m} \\
1.47, \mathrm{~m}\end{array}$ & 21.1 & $\begin{array}{l}1.58, \mathrm{~m} \\
1.47, \mathrm{~m}\end{array}$ & 19.9 & $\begin{array}{l}1.76, \mathrm{~m} \\
1.63, \mathrm{~m}\end{array}$ & 21.1 & $\begin{array}{l}1.57, \mathrm{~m} \\
1.46, \mathrm{~m}\end{array}$ \\
\hline 2 & 28.9 & $\begin{array}{l}1.69, \mathrm{~m} \\
1.46, \mathrm{~m}\end{array}$ & 28.9 & $\begin{array}{l}1.69, \mathrm{~m} \\
1.46, \mathrm{~m}\end{array}$ & 27.5 & $\begin{array}{l}1.87, \mathrm{~m} \\
1.12, \mathrm{~m}\end{array}$ & 28.9 & $\begin{array}{l}1.69, \mathrm{~m} \\
1.46, \mathrm{~m}\end{array}$ \\
\hline 3 & 76.6 & 3.47 , brt $(2.5)$ & 76.6 & 3.47, brt $(2.5)$ & 78.5 & $3.47, \mathrm{~s}$ & 76.6 & $3.47, \mathrm{~s}$ \\
\hline 4 & 41.4 & - & 41.4 & - & 39.4 & - & 41.4 & - \\
\hline 5 & 141.2 & - & 141.2 & - & 66.8 & - & 141.2 & - \\
\hline 6 & 121.4 & 5.59 , overlap & 121.5 & $5.59, \mathrm{~d}(5.9)$ & 53.2 & $3.16, \mathrm{~d}(5.8)$ & 121.5 & $5.59, \mathrm{~d}(5.7)$ \\
\hline 7 & 24.3 & $\begin{array}{l}2.39, \mathrm{~m} \\
1.79, \mathrm{~m}\end{array}$ & 24.3 & $\begin{array}{l}2.39, \mathrm{~m} \\
1.79, \mathrm{~m}\end{array}$ & 22.7 & $\begin{array}{l}2.21, \mathrm{~m} \\
1.71, \mathrm{~m}\end{array}$ & 24.4 & $\begin{array}{l}2.39, \mathrm{~m} \\
1.79, \mathrm{~m}\end{array}$ \\
\hline 8 & 43.6 & $1.76, \mathrm{~m}$ & 43.6 & $1.76, \mathrm{~m}$ & 42.4 & $1.67, \mathrm{~m}$ & 43.6 & $1.76, \mathrm{~m}$ \\
\hline 9 & 34.5 & - & 34.4 & - & 33.9 & - & 34.5 & - \\
\hline 10 & 37.8 & $2.26, \mathrm{~d}(12.1)$ & 37.8 & $2.26, \mathrm{~d}(12.3)$ & 35.2 & $2.21, \mathrm{~m}$ & 37.8 & $2.26, \mathrm{~d}(12.5)$ \\
\hline 11 & 32.3 & $\begin{array}{l}1.66, \mathrm{~m} \\
1.43, \mathrm{~m}\end{array}$ & 32.3 & $\begin{array}{l}1.64, \mathrm{~m} \\
1.43, \mathrm{~m}\end{array}$ & 33.6 & $\begin{array}{l}1.63, \mathrm{~m} \\
1.32, \mathrm{~m}\end{array}$ & 32.3 & $\begin{array}{l}1.66, \mathrm{~m} \\
1.43, \mathrm{~m}\end{array}$ \\
\hline 12 & 30.4 & $\begin{array}{l}1.71, \mathrm{~m} \\
1.46, \mathrm{~m}\end{array}$ & 30.4 & $\begin{array}{l}1.67, \mathrm{~m} \\
1.46, \mathrm{~m}\end{array}$ & 30.1 & $\begin{array}{l}1.64, \mathrm{~m} \\
1.46, \mathrm{~m}\end{array}$ & 30.4 & $\begin{array}{l}1.65, \mathrm{~m} \\
1.46, \mathrm{~m}\end{array}$ \\
\hline 13 & 46.3 & - & 46.2 & - & 45.8 & - & 46.2 & - \\
\hline 14 & 49.2 & - & 49.1 & - & 49.1 & - & 49.2 & - \\
\hline 15 & 34.8 & $\begin{array}{l}1.20, \mathrm{~m} \\
1.15, \mathrm{~m}\end{array}$ & 34.7 & $\begin{array}{l}1.20, \mathrm{~m} \\
1.14, \mathrm{~m}\end{array}$ & 34.6 & $\begin{array}{l}1.23, \mathrm{~m} \\
1.13, \mathrm{~m}\end{array}$ & 34.7 & $\begin{array}{l}1.20, \mathrm{~m} \\
1.14, \mathrm{~m}\end{array}$ \\
\hline 16 & 28.2 & $\begin{array}{l}1.24, \mathrm{~m} \\
1.16, \mathrm{~m}\end{array}$ & 27.9 & $\begin{array}{l}1.24, \mathrm{~m} \\
1.16, \mathrm{~m}\end{array}$ & 29.7 & $\begin{array}{l}1.88, \mathrm{~m} \\
1.24, \mathrm{~m}\end{array}$ & 27.9 & $\begin{array}{l}1.24, \mathrm{~m} \\
1.16, \mathrm{~m}\end{array}$ \\
\hline 17 & 50.1 & $1.57, \mathrm{~m}$ & 50.5 & $1.57, \mathrm{~m}$ & 50.4 & $1.48, \mathrm{~m}$ & 50.8 & $1.48, \mathrm{~m}$ \\
\hline 18 & 15.7 & $0.87, \mathrm{~s}$ & 15.4 & $0.85, \mathrm{~s}$ & 15.3 & $0.81, \mathrm{~s}$ & 15.4 & $0.86, \mathrm{~s}$ \\
\hline 19 & 28.0 & $0.92, \mathrm{~s}$ & 28.0 & $0.91, \mathrm{~s}$ & 27.1 & $1.01, \mathrm{~s}$ & 28.0 & $0.92, \mathrm{~s}$ \\
\hline 20 & 40.1 & $2.16, \mathrm{~m}$ & 36.3 & $1.45, \mathrm{~m}$ & 36.2 & $1.50, \mathrm{~m}$ & 35.8 & $1.45, \mathrm{~m}$ \\
\hline 21 & 20.4 & $1.00, \mathrm{~d}(6.6)$ & 18.9 & $0.91, \mathrm{~d}(6.6)$ & 18.6 & $0.88, \mathrm{~d}(5.9)$ & 18.7 & $0.91, \mathrm{~d}(5.3)$ \\
\hline 22 & 141.3 & 5.59 , overlap & 33.6 & $\begin{array}{l}1.75, \mathrm{~m} \\
0.99, \mathrm{~m}\end{array}$ & 39.1 & $\begin{array}{l}2.14, \mathrm{~m} \\
1.73, \mathrm{~m}\end{array}$ & 29.5 & $\begin{array}{l}1.05, \mathrm{~m} \\
0.92, \mathrm{~m}\end{array}$ \\
\hline 23 & 125.7 & $5.42, \mathrm{~m}$ & 28.6 & $\begin{array}{l}1.70, \mathrm{~m} \\
1.14, \mathrm{~m}\end{array}$ & 125.3 & 5.59 , overlap & 32.2 & $\begin{array}{l}1.64, \mathrm{~m} \\
1.43, \mathrm{~m}\end{array}$ \\
\hline 24 & 79.7 & $3.83, \mathrm{~d}(7.1)$ & 79.6 & $3.27, \mathrm{~d}(9.8)$ & 139.5 & 5.59 , overlap & 63.6 & $3.62, \mathrm{t}(6.2)$ \\
\hline 25 & 72.9 & - & 73.2 & - & 70.7 & - & 17.8 & $0.81, \mathrm{~s}$ \\
\hline 26 & 26.3 & $1.20, \mathrm{~s}$ & 26.5 & $1.20, \mathrm{~s}$ & 29.9 & $1.31, \mathrm{~s}$ & 27.2 & $1.03, \mathrm{~s}$ \\
\hline 27 & 23.7 & $1.14, \mathrm{~s}$ & 23.2 & $1.15, \mathrm{~s}$ & 30.0 & $1.31, \mathrm{~s}$ & 25.5 & $1.14, \mathrm{~s}$ \\
\hline 28 & 17.8 & $0.81, \mathrm{~s}$ & 17.8 & $0.80, \mathrm{~s}$ & 20.5 & $0.85, \mathrm{~s}$ & & \\
\hline 29 & 27.2 & $1.02, \mathrm{~s}$ & 27.2 & $1.02, \mathrm{~s}$ & 24.8 & $1.12, \mathrm{~s}$ & & \\
\hline 30 & 25.4 & $1.13, \mathrm{~s}$ & 25.4 & $1.13, \mathrm{~s}$ & 19.9 & $0.88, \mathrm{~s}$ & & \\
\hline
\end{tabular}

primarily the observation of an oxymethine and the absence of a methylene. In the ${ }^{1} \mathrm{H}-{ }^{1} \mathrm{H}$ COSY spectrum of $\mathbf{1}$, two mutual coupling olefinic protons exhibited the correlations with $\mathrm{H}-20$ and the oxygenated methine proton at $\delta_{\mathrm{H}} 3.83$ (Fig. 2), respectively, ascribing a double bond to $\mathrm{C}-22$ and C-23 positions. The HMBC correlation (Fig. 2) of $\mathrm{CH}_{3}-21$ with the olefinic carbon at $\delta_{\mathrm{C}} 141.3$ confirmed the above deduction. Also, the observation of HMBC correlations from $\mathrm{CH}_{3}-26$ and $\mathrm{CH}_{3}-27$ to $\mathrm{C}-24\left(\delta_{\mathrm{C}} 79.7\right)$ and the oxygenated quaternary carbon at $\delta_{\mathrm{C}} 72.9$ supported the hydroxyl substituents at C-24 and C-25 positions. The absolute configuration of C-24 in $\mathbf{1}$ was assigned using the Snatzke's method [9, 10]. Metal complex of compound $\mathbf{1}$ in DMSO gave a significant induced CD spectrum (ICD) (Fig. 4), in which the positive cotton effect observed at $315 \mathrm{~nm}$ permitted the assignment of a $24 S$ configuration for $\mathbf{1}$. The relative configurations of other stereocenters of $\mathbf{1}$ were established to be identical to those of known compound $\mathbf{9}$ due to NOESY experiment (Fig. 3). Thus, the structure of compound 1 was identified as cucurbita-5, 22-diene-3 $3,24 S$, 25-triol. 


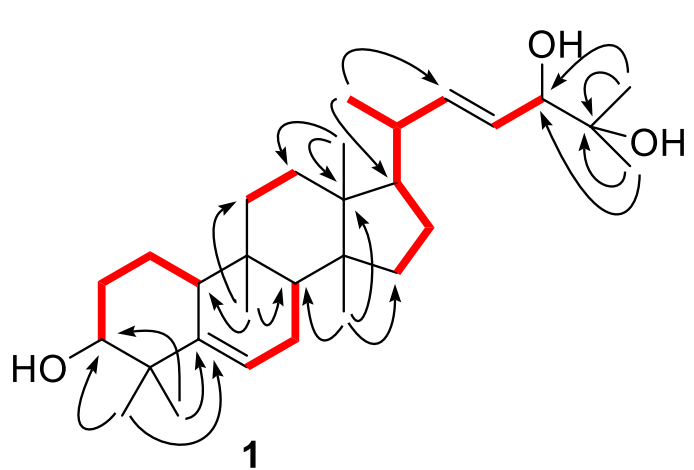

$\longrightarrow{ }^{1} \mathrm{H}-{ }^{1} \mathrm{H} \cos \mathrm{Y}$

Fig. 2 Selected ${ }^{1} \mathrm{H}-{ }^{1} \mathrm{H}$ COSY and HMBC correlations of $\mathbf{1}$ and $\mathbf{7}$

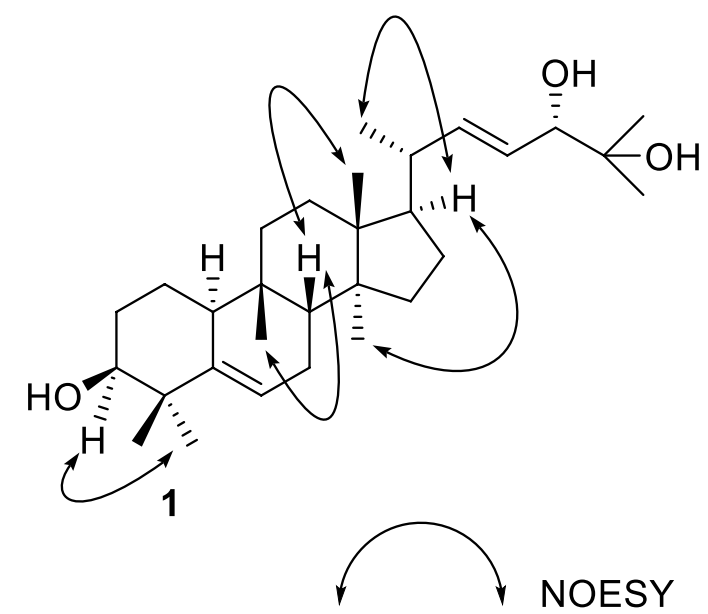

Fig. 3 Key NOESY correlations of $\mathbf{1}$ and $\mathbf{7}$

Compound 2 was obtained as white solid and assigned a molecular formula of $\mathrm{C}_{30} \mathrm{H}_{52} \mathrm{O}_{3}$ (HRESIMS $m / z 495.3622$ $\left[\mathrm{M}+\mathrm{Cl}^{-}\right.$, calcd for 495.3610), with two hydrogen atoms more than that of $\mathbf{1}\left(493.3447[\mathrm{M}+\mathrm{Cl}]^{-}\right)$. The ${ }^{1} \mathrm{H}$ and ${ }^{13} \mathrm{C}$ NMR spectra (Table 1 ) of $\mathbf{2}$ were very similar to $\mathbf{1}$, except that two olefinic protons of $\mathbf{1}$ were replaced by two methylenes in $\mathbf{2}$. Therefore, the structure of $\mathbf{2}$ was determined to be a hydrogenated derivative of $\mathbf{1}$ at $\mathrm{C}-22 / \mathrm{C}-23$ double bond. The assignment was confirmed by the ${ }^{1} \mathrm{H}-{ }^{1} \mathrm{H}$ COSY correlations of $\mathrm{CH}_{3}-21 / \mathrm{H}-20 / \mathrm{CH}_{2}-22 / \mathrm{CH}_{2}-23 / \mathrm{H}-24$ and key $\mathrm{HMBC}$ correlations of the oxygenated methine proton at $\delta_{\mathrm{H}}$ $3.31(\mathrm{H}-24)$ with $\mathrm{C}-22$ and $\mathrm{C}-23$, and of $\mathrm{CH}_{3}-26$ and $\mathrm{CH}_{3}-27$ with C-24 $\left(\delta_{\mathrm{C}} 79.6\right)$. Similarly, the absolute configuration of C-24 in 2 was confirmed using the Snatzke's method $[9,10]$. The positive Cotton effect observed at $310 \mathrm{~nm}$ (Fig. 4) permitted the assignment of a $24 S$ configuration for 2 . Thus, the structure of compound $\mathbf{2}$ was identified as cucurbita-5-ene-3 $\beta, 24 S, 25$-triol.

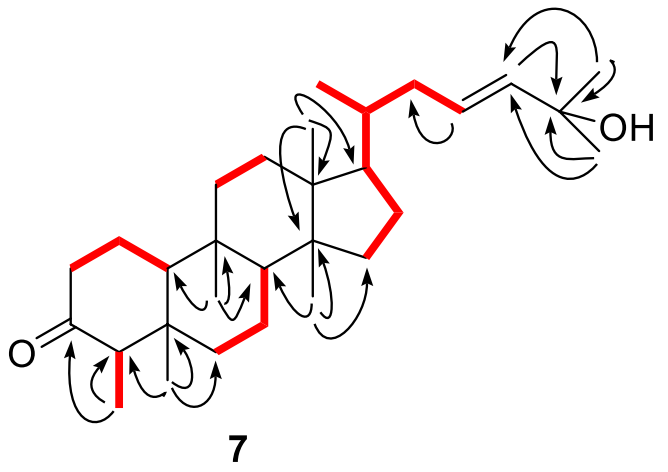

$\mathrm{H} C \mathrm{HMBC}$

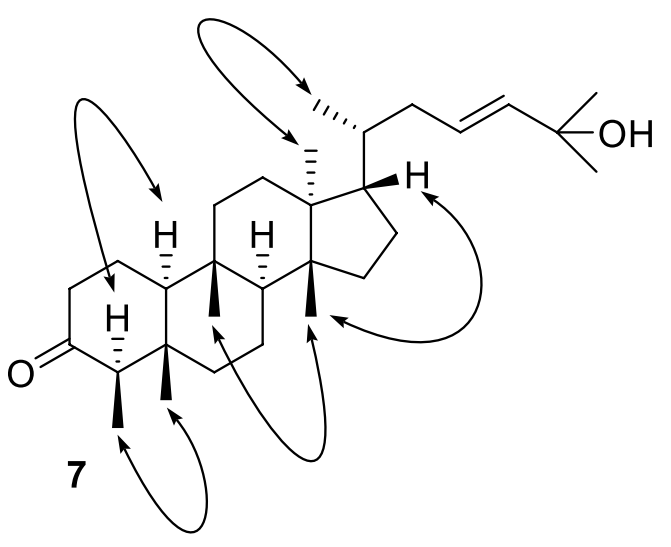

Compound $\mathbf{3}$ was isolated as white solid. Its molecular formula $\left(\mathrm{C}_{30} \mathrm{H}_{50} \mathrm{O}_{3}\right)$, ascertained via high resolution ESI-MS analysis, indicated six degrees of unsaturation. Detailed analysis of the NMR (Table 1) and MS spectra led to the conclusion that the only difference between $\mathbf{3}$ and known compound 9 was that there is an epoxide group between C-5 $\left(\delta_{\mathrm{C}} 66.8, \mathrm{~s}\right)$ and C-6 $\left(\delta_{\mathrm{C}} 53.2, \mathrm{~d}\right)$ in $\mathbf{3}$ instead of a double bond between C-5 $\left(\delta_{\mathrm{C}} 141.2, \mathrm{~s}\right)$ and C-6 $\left(\delta_{\mathrm{C}} 121.4, \mathrm{~d}\right)$ in 9. The epoxide group was elucidated by $\mathrm{HMBC}$ correlations of $\mathrm{H}-1, \mathrm{H}-3, \mathrm{H}-7, \mathrm{CH}_{3}-29$ and $\mathrm{CH}_{3}-30$ with C-5, and of $\mathrm{H}-8$ and $\mathrm{H}-10$ with $\mathrm{C}-6$, as well as the ${ }^{1} \mathrm{H}-{ }^{1} \mathrm{H}$ COSY correlations of $\mathrm{H}-6 / \mathrm{H}-7$. The NOESY correlations of $\mathrm{H}-6 / \mathrm{CH}_{3}-29$ indicated the epoxy ring of $\mathbf{3}$ was in $\beta$-orientation. Thus, the structure of compound $\mathbf{3}$ was identified as cucurbita- $5 \beta, 6 \beta$ epoxy-23-ene-3 $\beta, 25$-diol.

Compound 4 was obtained as white solid and assigned a molecular formula of $\mathrm{C}_{27} \mathrm{H}_{46} \mathrm{O}_{2}$, (HRESIMS $\mathrm{m} / z 403.3594$ $[\mathrm{M}+\mathrm{H}]^{+}$, calcd for 403.3571), indicating five degrees of 


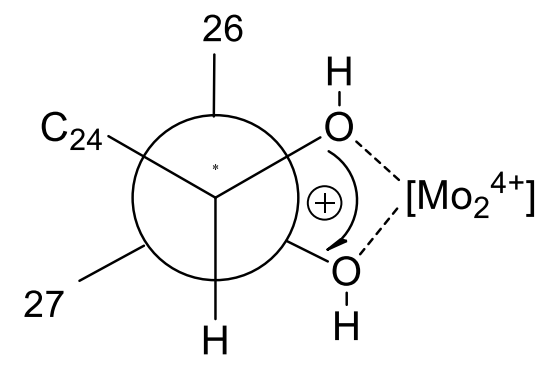

Favored Conformation

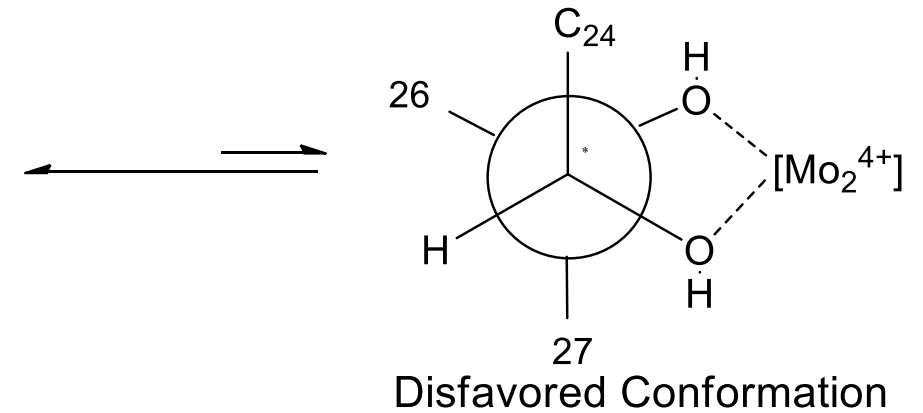

Disfavored Conformation
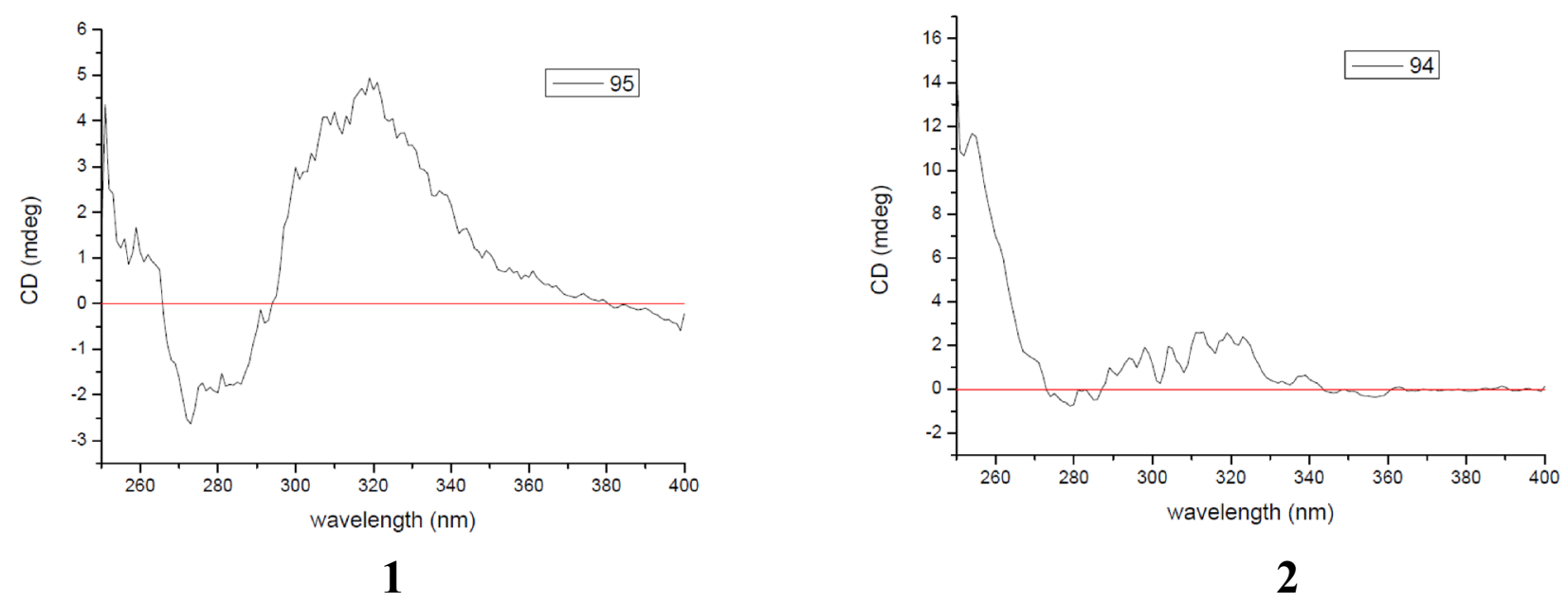

2

Fig. 4 Conformations and ICD spectra of the $\mathrm{Mo}_{2}^{4+}$ complex of $\mathbf{1}$ and $\mathbf{2}$ in DMSO

unsaturation. In the ${ }^{1} \mathrm{H}$ NMR spectrum (Table 1), the signals of five tertiary methyl groups $\left(\delta_{\mathrm{H}} 1.14,1.03,0.92\right.$, $0.86,0.81)$ and one secondary methyl group $\left(\delta_{\mathrm{H}} 0.91,3 \mathrm{H}\right.$, $\mathrm{d}, J=5.3 \mathrm{~Hz}$ ) were observed. The ${ }^{13} \mathrm{C}$ NMR spectrum of 4 showed signals for 27 carbons due to six methyl groups, two olefinic carbons, ten methylenes (including an oxygenated one), five methines (including an oxygenated one), and four quaternary carbons. Detailed comparison of the ${ }^{13} \mathrm{C}$ NMR spectrum of $\mathbf{4}$ with that of $\mathbf{2}$ displayed similarities in rings A-D, except for the absence of the signals for C-25, 26,27 . These evidences revealed that compound 4 is a rare 25,26,27-trinorcucurbitane triterpenoid. This can be confirmed via the ${ }^{1} \mathrm{H}-{ }^{1} \mathrm{H}$ COSY correlations of $\mathrm{H}_{3}-21 / \mathrm{H}-20 /$ $\mathrm{H}_{2}-22 / \mathrm{H}_{2}-23 / \mathrm{H}_{2}-24$. Thus, the structure of compound 4 was identified as 25,26,27-trinorcucurbita-5-ene-3 $\beta, 24$-diol.

Compound $\mathbf{5}$ was isolated as white solid. Its molecular formula $\left(\mathrm{C}_{27} \mathrm{H}_{44} \mathrm{O}_{3}\right)$, ascertained via high resolution ESI-MS analysis, indicated six degrees of unsaturation. Analysis of the ${ }^{1} \mathrm{H}$ and ${ }^{13} \mathrm{C}$ NMR spectroscopic data of 5 (Table 2) indicated a structural similarity with compound $\mathbf{4}$, except that compound 5 has a carboxyl $\left(\delta_{\mathrm{C}} 178.8, \mathrm{C}-24\right)$ instead of hydroxyl methyl signals in $\mathbf{4}$. The deduction was confirmed via the HMBC correlations from $\mathrm{H}-22, \mathrm{H}-23$ to the carboxyl carbon (C-24). The relative configurations of 5 were evidenced to be identical to those of $\mathbf{4}$ by analysis of NOESY spectrum. Thus, the structure of compound $\mathbf{5}$ was identified as 25,26,27-trinorcucurbita-5-ene-3 $\beta$-ol-24-acid (Table 3).

Analysis of HRESIMS spectrum ascribed compound 6 to a molecular formula $\mathrm{C}_{26} \mathrm{H}_{44} \mathrm{O}_{2}$ due to an adducting ion peak at $m / z 389.3442[\mathrm{M}+\mathrm{H}]^{+}$. The NMR data (Table 2) of 6 exhibited one methylene less than those of $\mathbf{4}$, which can be confirmed by key ${ }^{1} \mathrm{H}-{ }^{1} \mathrm{H}$ COSY correlations of $\mathrm{H}-21 / \mathrm{H}-20 / \mathrm{H}-22 / \mathrm{H}-23$ as well as HMBC correlation from hydroxyl methyl proton at $\delta_{\mathrm{H}} 3.68(2 \mathrm{H}, \mathrm{m})$ to C-20 $\left(\delta_{\mathrm{C}} 33.1\right)$. Thus, the structure of compound $\mathbf{6}$ was identified as a rare 24,25,26,27-tetranorcucurbitane triterpenoid, and named 24,25,26,27-tetranorcucurbita-5-ene-3 $\beta, 23$-diol.

The molecular formula of $7, \mathrm{C}_{30} \mathrm{H}_{50} \mathrm{O}_{2}$, was determined due to HRESIMS adducting ion peak at $\mathrm{m} / \mathrm{z} 443.3904$ $[\mathrm{M}+\mathrm{H}]^{+}$. The ${ }^{1} \mathrm{H}$ NMR spectroscopic data (Table 2) gave 
Table $2{ }^{1} \mathrm{H}(500 \mathrm{MHz})$ and ${ }^{13} \mathrm{C}$ (125 MHz) NMR spectroscopic data of compounds $\mathbf{5 - 8}$ in $\mathrm{CDCl}_{3}$

\begin{tabular}{|c|c|c|c|c|c|c|c|c|}
\hline \multirow[t]{2}{*}{ No. } & \multicolumn{2}{|c|}{ Compound $\mathbf{5}$} & \multicolumn{2}{|c|}{ Compound 6} & \multicolumn{2}{|c|}{ Compound 7} & \multicolumn{2}{|c|}{ Compound 8} \\
\hline & $\overline{\delta_{\mathrm{C}}}$ & $\delta_{\mathrm{H}}(J$ in $\mathrm{Hz})$ & $\delta_{\mathrm{C}}$ & $\delta_{\mathrm{H}}(J$ in $\mathrm{Hz})$ & $\delta_{\mathrm{C}}$ & $\delta_{\mathrm{H}}(J$ in $\mathrm{Hz})$ & $\delta_{\mathrm{C}}$ & $\delta_{\mathrm{H}}(J$ in $\mathrm{Hz})$ \\
\hline 1 & 21.1 & $\begin{array}{l}1.57, \mathrm{~m} \\
1.46, \mathrm{~m}\end{array}$ & 21.1 & $\begin{array}{l}1.58, \mathrm{~m} \\
1.47, \mathrm{~m}\end{array}$ & 22.7 & $\begin{array}{l}1.95, \mathrm{~m} \\
1.72, \mathrm{~m}\end{array}$ & 22.7 & $\begin{array}{l}1.95, \mathrm{~m} \\
1.72, \mathrm{~m}\end{array}$ \\
\hline 2 & 28.9 & $\begin{array}{l}1.69, \mathrm{~m} \\
1.46, \mathrm{~m}\end{array}$ & 28.9 & $\begin{array}{l}1.69, \mathrm{~m} \\
1.46, \mathrm{~m}\end{array}$ & 41.5 & $\begin{array}{l}2.40, \mathrm{~m} \\
2.33, \mathrm{~m}\end{array}$ & 41.5 & $\begin{array}{l}2.42, \mathrm{~m} \\
2.33, \mathrm{~m}\end{array}$ \\
\hline 3 & 76.6 & 3.47 , brt $(2.5)$ & 76.6 & 3.47 , brt $(2.5)$ & 213.2 & - & 213.1 & - \\
\hline 4 & 41.4 & - & 41.4 & - & 58.2 & $2.26, \mathrm{~m}$ & 58.2 & $2.26, \mathrm{~m}$ \\
\hline 5 & 141.3 & - & 141.2 & - & 42.4 & - & 42.4 & - \\
\hline 6 & 121.5 & $5.59, \mathrm{~d}(5.6)$ & 121.5 & $5.59, \mathrm{~d}(5.7)$ & 40.8 & $\begin{array}{l}1.74, \mathrm{~m} \\
1.34, \mathrm{~m}\end{array}$ & 40.8 & $\begin{array}{l}1.74, \mathrm{~m} \\
1.34, \mathrm{~m}\end{array}$ \\
\hline 7 & 24.4 & $\begin{array}{l}2.39, \mathrm{~m} \\
1.79, \mathrm{~m}\end{array}$ & 24.4 & $\begin{array}{l}2.39, \mathrm{~m} \\
1.79, \mathrm{~m}\end{array}$ & 20.3 & $\begin{array}{l}1.53, \mathrm{~m} \\
1.27, \mathrm{~m}\end{array}$ & 20.3 & $\begin{array}{l}1.53, \mathrm{~m} \\
1.27, \mathrm{~m}\end{array}$ \\
\hline 8 & 43.6 & $1.76, \mathrm{~m}$ & 43.6 & $1.76, \mathrm{~m}$ & 49.7 & $1.55, \mathrm{~m}$ & 49.7 & $1.55, \mathrm{~m}$ \\
\hline 9 & 34.5 & - & 34.5 & - & 37.8 & - & 37.8 & - \\
\hline 10 & 37.8 & $2.26, \mathrm{~m}$ & 37.8 & $2.26, \mathrm{~d}(12.1)$ & 59.0 & $1.58, \mathrm{~m}$ & 59.0 & $1.58, \mathrm{~m}$ \\
\hline 11 & 32.3 & $\begin{array}{l}1.64, \mathrm{~m} \\
1.43, \mathrm{~m}\end{array}$ & 32.3 & $\begin{array}{l}1.66, \mathrm{~m} \\
1.44, \mathrm{~m}\end{array}$ & 36.6 & $\begin{array}{l}1.43, \mathrm{~m} \\
1.39, \mathrm{~m}\end{array}$ & 36.7 & $\begin{array}{l}1.44, \mathrm{~m} \\
1.39, \mathrm{~m}\end{array}$ \\
\hline 12 & 30.4 & $\begin{array}{l}1.66, \mathrm{~m} \\
1.48, \mathrm{~m}\end{array}$ & 30.4 & $\begin{array}{l}1.69, \mathrm{~m} \\
1.49, \mathrm{~m}\end{array}$ & 30.0 & $\begin{array}{l}1.71, \mathrm{~m} \\
1.54, \mathrm{~m}\end{array}$ & 30.0 & $\begin{array}{l}1.71, \mathrm{~m} \\
1.54, \mathrm{~m}\end{array}$ \\
\hline 13 & 46.3 & - & 46.3 & - & 46.2 & - & 46.2 & - \\
\hline 14 & 49.2 & - & 49.2 & - & 48.1 & - & 48.1 & - \\
\hline 15 & 34.7 & $\begin{array}{l}1.20, \mathrm{~m} \\
1.14, \mathrm{~m}\end{array}$ & 34.7 & $\begin{array}{l}1.46, \mathrm{~m} \\
1.20, \mathrm{~m}\end{array}$ & 34.0 & $\begin{array}{l}2.23, \mathrm{~m} \\
1.20, \mathrm{~m}\end{array}$ & 34.0 & $\begin{array}{l}2.33, \mathrm{~m} \\
1.30, \mathrm{~m}\end{array}$ \\
\hline 16 & 27.8 & $\begin{array}{l}1.24, \mathrm{~m} \\
1.16, \mathrm{~m}\end{array}$ & 28.1 & $\begin{array}{l}1.87, \mathrm{~m} \\
1.15, \mathrm{~m}\end{array}$ & 27.9 & $\begin{array}{l}1.89, \mathrm{~m} \\
1.25, \mathrm{~m}\end{array}$ & 27.9 & $\begin{array}{l}1.89, \mathrm{~m} \\
1.24, \mathrm{~m}\end{array}$ \\
\hline 17 & 50.3 & $1.48, \mathrm{~m}$ & 50.8 & $1.51, \mathrm{~m}$ & 50.1 & $1.47, \mathrm{~m}$ & 50.4 & $1.46, \mathrm{~m}$ \\
\hline 18 & 15.4 & $0.86, \mathrm{~s}$ & 15.3 & $0.86, \mathrm{~s}$ & 36.2 & $1.53, \mathrm{~m}$ & 35.8 & $1.50, \mathrm{~m}$ \\
\hline 19 & 28.0 & $0.92, \mathrm{~s}$ & 28.0 & $0.92, \mathrm{~s}$ & 39.1 & $\begin{array}{l}2.16, \mathrm{~m} \\
1.75, \mathrm{~m}\end{array}$ & 31.9 & $\begin{array}{l}1.44, \mathrm{~m} \\
0.95, \mathrm{~m}\end{array}$ \\
\hline 20 & 35.5 & $1.48, \mathrm{~m}$ & 33.1 & $1.57, \mathrm{~m}$ & 125.4 & 5.59 , overlap & 31.5 & $\begin{array}{l}1.63, \mathrm{~m} \\
1.48, \mathrm{~m}\end{array}$ \\
\hline 21 & 18.3 & $0.91, \mathrm{~d}(5.3)$ & 18.9 & $0.93, \mathrm{~d}(5.3)$ & 139.4 & 5.59 , overlap & 76.7 & $4.02, \mathrm{t}(6.4)$ \\
\hline 22 & 30.9 & $\begin{array}{l}2.39, \mathrm{~m} \\
2.26, \mathrm{~m}\end{array}$ & 39.4 & $\begin{array}{l}1.72, \mathrm{~m} \\
1.23, \mathrm{~m}\end{array}$ & 70.7 & - & 147.4 & - \\
\hline 23 & 31.1 & $\begin{array}{l}1.81, \mathrm{~m} \\
1.30, \mathrm{~m}\end{array}$ & 61.0 & $3.68, \mathrm{~m}(2 \mathrm{H})$ & 6.8 & $0.87, \mathrm{~d}(6.5)$ & 6.8 & $0.86, d(6.5)$ \\
\hline 24 & 178.8 & - & 17.8 & $0.81, \mathrm{~s}$ & 14.6 & $0.72, \mathrm{~s}$ & 14.6 & $0.72, \mathrm{~s}$ \\
\hline 25 & 17.8 & $0.81, \mathrm{~s}$ & 27.2 & $1.02, \mathrm{~s}$ & 18.5 & $0.85, \mathrm{~s}$ & 18.5 & $0.85, \mathrm{~s}$ \\
\hline 26 & 27.2 & $1.03, \mathrm{~s}$ & 25.5 & $1.14, \mathrm{~s}$ & 19.2 & $0.78, \mathrm{~s}$ & 19.2 & $0.78, \mathrm{~s}$ \\
\hline 27 & 25.4 & $1.14, \mathrm{~s}$ & & & 15.8 & $0.88, \mathrm{~s}$ & 15.8 & $0.87, \mathrm{~s}$ \\
\hline 28 & & & & & 18.6 & $0.89, \mathrm{~d}(6.5)$ & 18.7 & $0.91, \mathrm{~d}(5.8)$ \\
\hline 29 & & & & & 30.0 & $1.30, \mathrm{~s}$ & 17.2 & $1.72, \mathrm{~s}$ \\
\hline 30 & & & & & 29.9 & $1.31, \mathrm{~s}$ & 111.4 & $\begin{array}{l}4.93, \mathrm{~m} \\
4.84, \mathrm{~m}\end{array}$ \\
\hline
\end{tabular}

two olefinic protons at $\delta_{\mathrm{H}} 5.59$ and eight methyls at $\delta_{\mathrm{H}} 0.87$ $(\mathrm{d}, 6.5 \mathrm{~Hz}), 0.72(\mathrm{~s}), 0.85(\mathrm{~s}), 0.78$ (s), 0.88 (s), 0.89 (d, $6.5 \mathrm{~Hz}), 1.30(\mathrm{~s}), 1.31(\mathrm{~s})$. The ${ }^{13} \mathrm{C}$ NMR spectrum revealed the presence of 30 carbon resonances which were sorted into eight methyl carbons, nine methylenes, and seven methine carbons, and six quaternary carbons by DEPT NMR spectrum. Detailed comparison of the NMR data of $\mathbf{7}$ with those of maytefolin $C$ [11] demonstrated that it possesses the same 18R-D:A-friedoeuphane skeleton, and differs from maytefolin C only at its side chain. The side chain of $\mathbf{7}$ was determined to be identical to that of known compound 9 by comparison of their ${ }^{1} \mathrm{H}$ and ${ }^{13} \mathrm{C}$ NMR chemical shifts (Table 2). This was further confirmed via the ${ }^{1} \mathrm{H}-{ }^{1} \mathrm{H}$ COSY correlations of $\mathrm{H}-18 / \mathrm{H}-28, \mathrm{H}-18 / \mathrm{H}-19 / \mathrm{H}-20$ and the key 
Table 3 Inhibitory effects of Compounds 1-9 against COX-2 in Vitro

\begin{tabular}{llll}
\hline Compounds & $\begin{array}{l}\mathrm{COX}-2 \\
\mathrm{IC}_{50}(\mu \mathrm{M})\end{array}$ & Compounds & $\begin{array}{l}\mathrm{COX}-2 \\
\mathrm{IC}_{50}(\mu \mathrm{M})\end{array}$ \\
\hline $\mathbf{1}$ & $>100$ & $\mathbf{6}$ & $31.02 \pm 2.64$ \\
$\mathbf{2}$ & $18.94 \pm 1.65$ & $\mathbf{7}$ & $>100$ \\
$\mathbf{3}$ & $>100$ & $\mathbf{8}$ & $>100$ \\
$\mathbf{4}$ & $3.98 \pm 0.32$ & $\mathbf{9}$ & $>100$ \\
$\mathbf{5}$ & $19.48 \pm 1.87$ & NS-398 & $4.14 \pm 0.28$ \\
\hline
\end{tabular}

HMBC correlations from $\mathrm{H}-21, \mathrm{CH}_{3}-29, \mathrm{CH}_{3}-30$ to C-22, and from $\mathrm{H}-20$ to $\mathrm{C}-19$ (Fig. 2). The relative configurations of 7 were assigned as shown in Fig. 3 by analysis of the NOESY spectrum (Fig. 3). Thus, the structure of compound 7 was identified as 18R-D:A-friedoeuph-20-ene-22-ol-3-one.

Compound $\mathbf{8}$ was obtained as yellow solid, and had the same molecular formula as $7\left(\mathrm{C}_{30} \mathrm{H}_{50} \mathrm{O}_{2}\right)$, as ascertained via HRESIMS adducting ion peak at $\mathrm{m} / z 443.3924[\mathrm{M}+\mathrm{H}]^{+}$. Detailed comparison of the NMR data with those of 7 revealed that 8 possessed a $18 R$-D:A-friedoeuphane skeleton as well, differing from $\mathbf{7}$ only in the positions of the double bond and the oxymethine at the side chain. The HMBC correlations from $\mathrm{CH}_{3}-29$ to two olefinic carbons at $\delta_{\mathrm{C}} 147.4$ and 111.4 disclosed that a terminal double bond was placed at C-22 and C-30 positions. A hydroxyl was substituted at C-21 due to key HMBC correlations of $\mathrm{CH}_{3}-29$ and $\mathrm{H}-30$ with the oxygenated methine carbon at $\delta_{\mathrm{C}} 76.7$. The absolute configuration of C-21 was assigned as $S$ on the basis of comparison of the chemical shifts of C-21 $\left(\delta_{\mathrm{C}} 76.7\right)$ and $\mathrm{H}-21\left(\delta_{\mathrm{H}} 4.02,1 \mathrm{H}, \mathrm{t}, J=6.4 \mathrm{~Hz}\right)$ with those in literature [12]. Thus, the structure of compound 8 was identified as 18R-D:A-friedoeuph-22(30)-en-21S-ol-3-one.

All compounds were evaluated for their COX-2 inhibitory activities with NS-398 as a positive control. The results (Table 3) exhibited that compound 4 had the most potent inhibition against $\mathrm{COX}-2$ with $\mathrm{IC}_{50}$ values of $3.98 \pm 0.32 \mu \mathrm{M}$, while compounds $\mathbf{2}, \mathbf{5}$ and $\mathbf{6}$ showed mild inhibitory effects with $\mathrm{IC}_{50}$ values of $18.94 \pm 1.65$, $19.48 \pm 1.87$ and $31.02 \pm 2.64 \mu \mathrm{M}$. Compounds $\mathbf{1}-\mathbf{6}$ and 9 share similar or even the same rings A, B, C, D, and the major difference is their side chains. Therefore, it seems that the side chain is the main factor to influence the inhibitions of compounds 1-6 and 9 against COX-2.

\section{Conclusion}

In conclusion, this research led to the isolation of eight new triterpenoids and one known triterpenoid from the A. latifolia, in which compounds 4-6 are rare trinorcucurbitane or tetranorcucurbitane triterpenoids. It is the first report of cucurbitane-type triterpenoids from the genus Ainsliaea.
Interestingly, compound $\mathbf{4}$ showed potent inhibition against COX-2 with $\mathrm{IC}_{50}$ values of $3.98 \pm 0.32 \mu \mathrm{M}$. These results imply, except for sesquiterpenoids, triterpenoids may be another type of important chemical constituents being responsible for anti-inflammation in Ainsliaea species. Therefore, more attention should be paid to structural novel triterpenoids of Ainsliaea plants.

\section{Experimental Section}

\subsection{General Experimental Procedures}

Optical rotations were measured on a PerkineElmer 341 polarimeter. ${ }^{1} \mathrm{H}$ and ${ }^{13} \mathrm{C}$ NMR spectra were recorded on Bruker Avance-500 spectrometers. ESI-MS were measured on an Agilent LC/MSD Trap XCT spectrometer, and HRESIMS were performed on an Agilent 6520 AccurateMS Q-TOF LC/MS system. A preparative column (ZORBAX-ODS GSA10250AP1301, C18, $5 \mu \mathrm{m}, 250 \times 10 \mathrm{~mm}$ ) was used for semi-preparative HPLC (Shimadzu LC-2010A HT). TLC analysis was run on $\mathrm{HSGF}_{254}$ silica gel plates (10-40 $\mu \mathrm{m}$, Yantai, China). Column chromatography (CC) was performed on silica (100-200, 200-300 mesh, Yantai, China), YMC-GEL ODS-A (50 $\mu \mathrm{m}$, YMC, Japan), Sephadex LH-20 (Amersham Pharmacia Biotech AB, Uppsala, Sweden).

\subsection{Plant Material}

The dried whole plants of A. latifolia were collected from Guiyang city of Guizhou province, PR China in September 2013, and authenticated by Prof. Long Qing-De, Department of Pharmacognosy, School of Pharmacy, Guiyang Medical University. An authentic specimen (No. 20130905) was deposited at the School of Pharmacy, Second Military Medical University.

\subsection{Extraction and Isolation}

The dried whole plants of A. latifolia $(15.0 \mathrm{~kg})$ were powdered and extracted with EtOH- $\mathrm{H}_{2} \mathrm{O}(80: 20$, v/v) twice at room temperature, $48 \mathrm{~h}$ each time. The combined $\mathrm{EtOH}$ extracts were concentrated in vacuo to yield a crude extract $(2.0 \mathrm{~kg})$ which was then successfully partitioned with petroleum ether (PE), $\mathrm{CHCl}_{3}$, EtOAc, and $\mathrm{MeOH}$, respectively, The $\mathrm{CHCl}_{3}$ fraction (105 g) was chromatographed on a silica gel column, eluting with gradient PE/EtOAc (100:1; $50: 1 ; 20: 1 ; 10: 1 ; 5: 1)$ to give six fractions $(\mathrm{F} 1: 19.2 \mathrm{~g}, \mathrm{~F} 2$ : 5.2 g, F3: 7.3 g, F4: 21.7 g, F5: 7.9 g, F6: 13.1 g). Fraction F2 was subjected to column chromatography (CC) over Sephadex LH-20 (MeOH) and silica gel to give compounds 7 (12.0 mg), 8 (4.2 mg). Fraction F3 was separated 
over Sephadex LH-20 (MeOH) followed by semi-preparative HPLC $\left(\mathrm{CH}_{3} \mathrm{CN}-\mathrm{H}_{2} \mathrm{O}, 100: 0\right)$, to yield $\mathbf{1}(3.0 \mathrm{mg}), 2$ $(9.0 \mathrm{mg})$, and $\mathbf{3}(9.4 \mathrm{mg})$, respectively. Fraction F4 was subjected to ODS CC, eluted with a $\mathrm{MeOH}-\mathrm{H}_{2} \mathrm{O}$ gradient, to yield 10 subfractions (F4A-F4 J). Subfraction F4B (507 mg) was subjected to CC over Sephadex LH-20 (MeOH) and silica gel to give compounds $4(4.0 \mathrm{mg}), \mathbf{5}(4.2 \mathrm{mg}), \mathbf{6}(3.2 \mathrm{mg})$ and $\mathbf{9}(11.7 \mathrm{mg})$.

\subsubsection{Cucurbita-5,22-diene-3 $\beta, 245,25-$ triol (1)}

White solid; $[\alpha]_{\mathrm{D}}^{20}+18.7\left(c\right.$ 0.10, $\left.\mathrm{CHCl}_{3}\right)$; UV $(\mathrm{MeOH})$ $\lambda_{\max }(\log \varepsilon) 204$ (3.71) nm; For ${ }^{1} \mathrm{H}$ NMR and ${ }^{13} \mathrm{C}$ NMR spectroscopic data, see Table 1; HRESIMS m/z 493.3447 $[\mathrm{M}+\mathrm{Cl}]^{-}$(calcd for $\left.\mathrm{C}_{30} \mathrm{H}_{50} \mathrm{O}_{3}, 493.3454\right)$.

\subsubsection{Cucurbita-5-ene-3 $\beta, 24 S, 25$-triol (2)}

White solid; $[\alpha]_{\mathrm{D}}^{20}+46.6\left(c\right.$ 0.30, $\left.\mathrm{CHCl}_{3}\right)$; $\mathrm{UV}(\mathrm{MeOH})$ $\lambda_{\max }(\log \varepsilon) 204$ (3.72) nm; For ${ }^{1} \mathrm{H}$ NMR and ${ }^{13} \mathrm{C}$ NMR spectroscopic data, see Table 1; HRESIMS $\mathrm{m} / \mathrm{z} 495.3622$ $[\mathrm{M}+\mathrm{Cl}]^{-}$(calcd for $\mathrm{C}_{30} \mathrm{H}_{52} \mathrm{O}_{3}, 495.3610$ ).

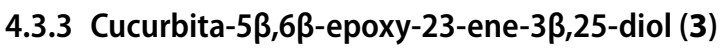

White solid; $[\alpha]_{\mathrm{D}}^{20}+1.7\left(c 0.13, \mathrm{CHCl}_{3}\right)$; UV (MeOH) $\lambda_{\max }$ ( $\log \varepsilon) 201$ (3.62), 203 (3.69), 231 (3.52) nm; For ${ }^{1} \mathrm{H}$ NMR and ${ }^{13} \mathrm{C}$ NMR spectroscopic data, see Table 1; HRESIMS $m / z, 493.3457[\mathrm{M}+\mathrm{Cl}]^{-}$(calcd for $\left.\mathrm{C}_{30} \mathrm{H}_{50} \mathrm{O}_{3}, 493.3454\right)$.

\subsubsection{Cucurbita-5-ene-3 $\beta, 24$-diol (4)}

White solid; $[\alpha]_{\mathrm{D}}^{20}+48.0\left(c 0.31, \mathrm{CHCl}_{3}\right) ; \mathrm{UV}(\mathrm{MeOH})$ $\lambda_{\max }(\log \varepsilon) 205$ (3.73), 207 (3.71) nm; For ${ }^{1} \mathrm{H}$ NMR and ${ }^{13} \mathrm{C}$ NMR spectroscopic data, see Table 1; HRESIMS $\mathrm{m} / \mathrm{z}$ $403.3594[\mathrm{M}+\mathrm{H}]^{+}\left(\right.$calcd for $\left.\mathrm{C}_{27} \mathrm{H}_{46} \mathrm{O}_{2}, 403.3571\right)$.

\subsubsection{Cucurbita-5-ene-3ß-ol-24-acid (5)}

White solid; $[\alpha]_{\mathrm{D}}^{20}+32.7\left(c 0.08, \mathrm{CHCl}_{3}\right) ; \mathrm{UV}(\mathrm{MeOH})$ $\lambda_{\max }(\log \varepsilon) 203$ (3.64) nm; For ${ }^{1} \mathrm{H}$ NMR and ${ }^{13} \mathrm{C}$ NMR spectroscopic data, see Table 2; HRESIMS $m / z 451.2980$ $[\mathrm{M}+\mathrm{Cl}]^{-}$(calcd for $\left.\mathrm{C}_{27} \mathrm{H}_{44} \mathrm{O}_{3}, 451.2984\right)$.

\subsubsection{Cucurbita-5-ene-3 $\beta, 23$-diol (6)}

White solid; $[\alpha]_{\mathrm{D}}^{20}+9.3\left(c 0.11, \mathrm{CHCl}_{3}\right)$; UV (MeOH) $\lambda_{\max }$ (log ع) 205 (3.54) nm; For ${ }^{1} \mathrm{H}$ NMR and ${ }^{13} \mathrm{C}$ NMR spectroscopic data, see Table 2; HRESIMS $m / z 389.3442[\mathrm{M}+\mathrm{H}]^{+}$ (calcd for $\mathrm{C}_{26} \mathrm{H}_{44} \mathrm{O}_{2}, 389.3414$ ).
4.3.7 18R-D:A-friedoeuph-20-ene-22-ol-3-one (7)

White solid; $[\alpha]_{\mathrm{D}}^{20}-17.4\left(c 0.37, \mathrm{CHCl}_{3}\right)$; UV $(\mathrm{MeOH})$ $\lambda_{\max }(\log \varepsilon) 207$ (3.18), 231 (3.28) nm; For ${ }^{1} \mathrm{H}$ NMR and

${ }^{13} \mathrm{C}$ NMR spectroscopic data, see Table 2; HRESIMS $\mathrm{m} / \mathrm{z}$ $443.3904[\mathrm{M}+\mathrm{H}]^{+}$(calcd for $\left.\mathrm{C}_{30} \mathrm{H}_{50} \mathrm{O}_{2}, 443.3884\right)$.

\subsubsection{R-D:A-friedoeuph-22-en-21S-ol-3-one (8)}

White solid; $[\alpha]_{\mathrm{D}}^{20}-37.9\left(c 0.15, \mathrm{CHCl}_{3}\right)$; UV $(\mathrm{MeOH})$ $\lambda_{\max }(\log \varepsilon) 201$ (3.44), 203 (3.54) nm; For ${ }^{1} \mathrm{H}$ NMR and ${ }^{13} \mathrm{C}$ NMR spectroscopic data, see Table 2; HRESIMS $\mathrm{m} / \mathrm{z}$ $443.3924[\mathrm{M}+\mathrm{H}]^{+}\left(\right.$calcd for $\left.\mathrm{C}_{30} \mathrm{H}_{50} \mathrm{O}_{2}, 443.3884\right)$.

\subsubsection{Cucurbita-5,23-diene-3 $\beta, 25$-diol (9)}

White solid, $\mathrm{C}_{30} \mathrm{H}_{50} \mathrm{O}_{2} ;{ }^{1} \mathrm{H}$ NMR $\left(500 \mathrm{MHz}, \mathrm{CDCl}_{3}\right): \delta_{\mathrm{H}}$ $0.79\left(3 \mathrm{H}, \mathrm{CH}_{3}-30\right), 0.85\left(3 \mathrm{H}, \mathrm{s}, \mathrm{CH}_{3}-18\right), 0.87(3 \mathrm{H}, \mathrm{d}$, $\left.J=5.8 \mathrm{~Hz}, \mathrm{CH}_{3}-21\right), 0.91\left(3 \mathrm{H}, \mathrm{s}, \mathrm{CH}_{3}-19\right), 1.02(3 \mathrm{H}, \mathrm{s}$, $\left.\mathrm{CH}_{3}-28\right), 1.13\left(3 \mathrm{H}, \mathrm{s}, \mathrm{CH}_{3}-29\right), 1.30\left(2 \times \mathrm{CH}_{3}, \mathrm{~s}, \mathrm{CH}_{3}-26\right.$, 27), $2.26(1 \mathrm{H}, \mathrm{d}, J=12.1 \mathrm{~Hz}, \mathrm{H}-10), 2.38(1 \mathrm{H}, \mathrm{m}, \mathrm{H}-7)$, $3.47(1 \mathrm{H}$, br.t, $J=2.5 \mathrm{~Hz}, \mathrm{H}-3), 5.58$ (3H, m, H-6, 23, 24); ${ }^{13} \mathrm{C}$ NMR $\left(125 \mathrm{MHz}, \mathrm{CDCl}_{3}\right): \delta_{\mathrm{C}} 21.1(\mathrm{t}, \mathrm{C}-1), 28.9(\mathrm{t}$, C-2), 76.6 (d, C-3), 41.4 (s, C-4), 141.2 (s, C-5), 121.4 (d, C-6), 24.3 (t, C-7), 43.6 (d, C-8), 34.5 (s, C-9), 37.8 (d, C-10), 32.3 (t, C-11), 30.3 (t, C-12), 46.3 (s, C-13), 49.2 (s, C-14), 34.8 (t, C-15), 27.8 (t, C-16), 50.1 (d, C-17), 15.4 (q, C-18), 28.0 (q, C-19), 36.2 (d, C-20), 18.7 (q, C-21), 39.1 (t, C-22), 125.5 (d, C-23), 139.4 (d, C-24), 70.7 (s, C-25), 29.8 (q, C-26), 29.9 (q, C-27), 17.8 (q, C-30), 27.2 (q, C-28), 25.4 (q, C-29); ESI-MS: $m / z 465[\mathrm{M}+\mathrm{Na}]^{+}$(positive), 441 $[\mathrm{M}-\mathrm{H}]^{-}$(negative).

\subsection{Determination of the Absolute Configuration of C-24 in Compounds 1 and 2}

According to the published literature $[9,10]$, a mixture of compound $1(1.1 \mathrm{mg})$ and $\mathrm{Mo}_{2}(\mathrm{OAc})_{4}(1.2 \mathrm{mg})$ was prepared for $\mathrm{CD}$ measurement. The mixture was kept for $30 \mathrm{~min}$ to form a stable chiral metal complex, the $\mathrm{CD}$ spectrum of which was then recorded. The observed sign of the diagnostic ICD (induced CD spectrum) curve at around $315 \mathrm{~nm}$ was correlated with the absolute configuration of C-24 in compound 1. Compound 2 was also dealt with the same method as $\mathbf{1}$.

\subsection{COX-2 Inhibitory Effect Assay}

Cayman's Colorimetric COX Inhibitor Screening Assay provides a convenient method for human recombinant COX-2 to screen isozyme-specific inhibitors. The assay measures the peroxidase component of COXs. The peroxidase activity is assayed colorimetrically by monitoring the appearance 
of oxidized $\mathrm{N}^{\prime}, \mathrm{N}, \mathrm{N}, \mathrm{N}^{\prime}$-tetramethyl-p-phenylenediamine (TMPD) at $590 \mathrm{~nm}$. The COX-2 assay consisted of a $200 \mu \mathrm{L}$ reaction mixture containing $150 \mu \mathrm{L}$ assay buffer, $10 \mu \mathrm{L}$ Heme, $10 \mu \mathrm{L}$ COX-2, $20 \mu \mathrm{L}$ Colorimetric Substrate, and $10 \mu \mathrm{L}$ test solution $\left(1,5,10,20,80,100 \mu \mathrm{mol} \cdot \mathrm{L}^{-1}\right)$. The reactions were initiated by quickly adding $10 \mu \mathrm{L}$ Arachidonic Acid, then incubating for $2 \mathrm{~min}$ at room temperature [13].

Acknowledgements The work was supported by NSFC (Nos. 81573318, 31870327, 81230090, 81520108030, 1302658), National Major Project of China (No. 2018ZX09731016-005), The Key Research and Development Program of China (Nos. 2017YFC1702002, 2017YFC1700200), Professor of Chang Jiang Scholars Program, Scientific Foundation of Shanghai China (Nos. 17431902800, 16401901300), Shanghai Engineering Research Center for the Preparation of Bioactive Natural Products (No. 10DZ2251300).

\section{Compliance with Ethical Standards}

Conflict of interest The authors declare that there are no conflicts of interest.

Open Access This article is distributed under the terms of the Creative Commons Attribution 4.0 International License (http://creativeco mmons.org/licenses/by/4.0/), which permits unrestricted use, distribution, and reproduction in any medium, provided you give appropriate credit to the original author(s) and the source, provide a link to the Creative Commons license, and indicate if changes were made.

\section{References}

1. Z.J. Wu, X.K. Xu, H.W. Zeng, Y.H. Shen, J.M. Tian, J. Su, H.L. Li, L. Shan, R.H. Liu, W.D. Zhang, Planta Med. 77, 1545-1550 (2011)

2. Y. Wang, Y.H. Shen, H.Z. Jin, J.J. Fu, X.J. Hu, J.J. Qin, J.H. Liu, M. Chen, S.K. Yan, W.D. Zhang, Org. Lett. 10, 5517-5520 (2008)

3. Z.J. Wu, X.K. Xu, Y.H. Shen, J. Su, J.M. Tian, S. Liang, H.L. Li, R.H. Liu, W.D. Zhang, Org. Lett. 10, 2397-2400 (2008)

4. F. Hilmi, J. Gertsch, P. Bremner, S. Valovic, M. Heinrich, O. Sticher, J. Heilmann, Bioorgan. Med. Chem. 11, 3659-3663 (2003)

5. M.T. Lindenmeyer, A. Hrenn, C. Kern, V. Castro, R. Murillo, S. Müller, S. Laufer, J. Schulte-Mönting, B. Siedle, I. Merfort, Bioorgan. Med. Chem. 14, 2487-2497 (2006)

6. R.T. Zeng, X.Y. Dong, X. Fang, N. Yang, Z.R. Shi, Z.G. Zhuo, Y.H. Shen, W.D. Zhang, Chem. Biodivers. 14, 1600 (2017)

7. Z.Y. Wu, Flora of Yunnan, vol. 13 (Science Press, Beijing, 2004), p. 642

8. S. Nakano, Y. Fujimoto, Y. Takaishi, C. Osorio, C. Duque, Fitoterapia 75, 609-611 (2004)

9. M. Górecki, E. Jabłońska, A. Kruszewska, A. Suszczyńska, Z. Urbańczyk-Lipkowska, M. Gerards, J.W. Morzycki, W.J. Szczepek, J. Frelek, J. Org. Chem. 72, 2906-2916 (2007)

10. L. Di Bari, G. Pescitelli, C. Pratelli, D. Pini, P. Salvadori, J. Org. Chem. 66, 4819-4825 (2001)

11. A. Ohsaki, Y. Imai, M. Naruse, S. Ayabe, K. Komiyama, J. Takashima, J. Nat. Prod. 67, 469-471 (2004)

12. W.B. Zhou, G.Z. Zeng, H.M. Xu, W.J. He, N.H. Tan, Molecules 18, 14585-14596 (2013)

13. Z.C. Yang, W.L. Lu, X.Y. Ma, D.D. Song, Phytomedicine 19, 301-305 (2012)

\section{Affiliations}

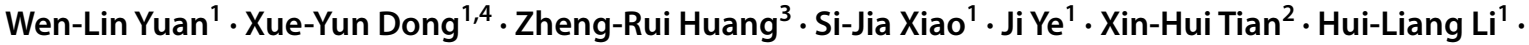 Yun-Heng Shen ${ }^{1}\left[\right.$ ( ) Wei-Dong Zhang ${ }^{1,2}$}

1 Department of Phytochemistry, School of Pharmacy, Naval Medical University (Second Military Medical University), Shanghai 200433, China

2 Interdisciplinary Science Research Institute, Shanghai University of Traditional Chinese Medicine,

Shanghai 201203, China
3 Department of Applied Chemistry, Xi' an University of Technology, Xi'an 710048, China

4 School of Pharmacy, Fujian University of Traditional Chinese Medicine, Fujian 350108, China 